\title{
A UNIVERSITY COURSE TO FACILITATE THE \\ TRANSITION INTO, THROUGH, AND BEYOND COLLEGE LIFE
}

\author{
A Project \\ Presented to \\ The Faculty of California Polytechnic State University \\ San Luis Obispo
}

\author{
In Partial Fulfillment \\ Of the Requirements for the Degree \\ Master of Science in Kinesiology \\ By \\ Matthew Aaron Crivello
}

June 2010 
Matthew Aaron Crivello

ALL RIGHTS RESERVED 
COMMITTEE MEMBERSHIP

TITLE:

A University Course to Facilitate the

Transition Into, Through, and Beyond College Life

AUTHOR:

Matthew Aaron Crivello

DATE SUBMITTED:

June 2010

COMMITTEE CHAIR:

Camille P. O'Bryant, Ph. D.

COMMITTEE MEMBER:

Kellie Green Hall, Ph. D.

COMMITTEE MEMBER: Michael Sutliff, P. E. D. 


\author{
ABSTRACT \\ A University Course to Facilitate the \\ Transition Into, Through, and Beyond College Life \\ Matthew Aaron Crivello
}

The purpose of this project was to review the literature associated with the social and psychological adjustments freshmen and transfer intercollegiate athletes face as they transition into college and create a mandatory course to assist them through their transition into California Polytechnic State University. This project led to the creation of an academic course that will be offered at California Polytechnic State University in the near future. This course could serve as an impetus for coaches, faculty, and administrators at other universities to develop similar courses, or reevaluate established course offerings, and to develop follow-up course training for intercollegiate athletes that will contribute to their positive growth throughout the course of their college careers. 


\section{ACKNOWLEDGEMENTS}

I would like to take this opportunity to give special thanks to the members of my committee: Dr. Camille O'Bryant, Dr. Kellie Green Hall, and Dr. Michael Sutliff for sharing their time, knowledge, and insight with me as I worked to complete this project. I would also like to thank the many university instructors who provided valuable information regarding the intercollegiate athlete support services offered at their respective universities. In addition, I would like to thank the former California Polytechnic State University alumni who shared their personal stories. Further, thanks go to the researchers who took their time to respond personally to my questions. Special thanks go to Dr. Colette Frayne for sharing her expertise and insight regarding self-management training principles and techniques. Finally, l'd like to thank all the coaches and instructors who played an instrumental role in my development as a person, an intercollegiate athlete, and, ultimately, as a coach who is in a position to make a difference in the lives of the intercollegiate athletes with whom I work. Without their longstanding and continual guidance, I might not be in the position to conduct this present undertaking. It is with great thanks and gratitude that this project is dedicated to the legacy of those who have, through their individual efforts, led a collective charge to positively affect my life. 


\section{TABLE OF CONTENTS}

\section{CHAPTER}

\section{INTRODUCTION}

$\begin{array}{ll}\text { Background of the Problem } & 1\end{array}$

Problem Statement 3

$\begin{array}{ll}\text { Purpose Statement } & 3\end{array}$

Guiding Questions 3

Justification Statement 4

$\begin{array}{lr}\text { Guiding Principles } & 6\end{array}$

$\begin{array}{lr}\text { Limitations } & 6\end{array}$

$\begin{array}{ll}\text { Operational Definitions } & 7\end{array}$

II. LITERATURE REVIEW

$\begin{array}{lr}\text { Introduction } & 9\end{array}$

Evolution of Intercollegiate Sports in the United States 9

$\begin{array}{ll}\text { Socialization into Sport } & 14\end{array}$

$\begin{array}{ll}\text { Socialization out of Sport } & 17\end{array}$

$\begin{array}{ll}\text { Life after Sport } & 19\end{array}$

$\begin{array}{ll}\text { Social Identity Theory } & 19\end{array}$

$\begin{array}{ll}\text { Social Cognitive Theory } & 21\end{array}$

Social and Psychological Issues and Challenges 22

Underuse of Support Services $\quad 25$

Barriers and Obstacles to Using Support Services 25

NCAA CHAMPS/Life Skills Program 26 
Self Management Training for Improving Performance

Summary

III. METHODS AND PROCEDURES

$\begin{array}{ll}\text { Course Purpose } & 30\end{array}$

Gathering Resources for Course Content 30

Course Structure 31

Course Outcomes, Objectives, and Assessment 31

Course Topics 33

Course Requirements and Activities Description 33

IV. CONCLUSION

$\begin{array}{ll}\text { Personal Reflection } & 36\end{array}$

Suggestions for Future Research 37

$\begin{array}{ll}\text { References } & 38\end{array}$

Appendix A - Reflections of Former Intercollegiate Athletes $\quad 49$

Appendix B - Course Syllabus $\quad 54$

$\begin{array}{ll}\text { Appendix C - Course Rubrics } & 60\end{array}$ 


\section{Chapter 1}

Introduction

\section{Background of the Problem}

Transition to college life can be difficult for any student (Hudd, Dumlao, ErdmannSager, Murray, Phan, Soukas, \& Yokozuka, 2000; Wilson \& Pritchard, 2005). However, researchers suggest that intercollegiate athletes experience significantly more difficulties due to the expectation that they perform both athletically and academically (Kimball \& Freysinger, 2003; Papanikolaou, Nikolaidis, Patsiaouras, \& Alexopoulos, 2003). In addition to the academic demands faced by all college students, athletes must cope with athletic related issues such as stress of performance, time management due to practice and competitive events, physical injury, and sports-related career transitions (Broughton \& Neyer, 2001; Watson \& Kissinger, 2007). Intercollegiate athletes, who are expected to fill multiple roles, can experience role strain in which commitment to one role detracts from the commitment to another. Adler and Adler (1991) found that many intercollegiate athletes are likely to involve themselves almost exclusively in their athletic role while at the same time disengaging themselves from their academic commitments. Intercollegiate athletes who do not disengage, attempt to cope with the internal and external pressures related to their dual role, and often face risks for personal and mental health issues.

According to Watson (2005) an increasing number of intercollegiate athletes experience adjustment problems, emotional concerns, and psychological distress due to their sport's participation. Nearly $10 \%$ to $15 \%$ of intercollegiate athletes face psychological issues severe enough to justify professional counseling intervention 
(Ferrante, Etzel, \& Lantz, 1996; Hinkle, 1994; Murray, 1997) compared to 8\%-9\% of the general college population (Gallagher, 2005). Despite the obvious need for support services, intercollegiate athletes usually underuse these resources (Ferraro \& Rush, 2000; Watson, 2005).

The National Collegiate Athletic Association (NCAA) mandates comprehensive rules to strengthen academic success. They also monitor graduation rates with penalties for underperformance. In addition, the NCAA requires universities to submit annual documentation to demonstrate compliance. As a result, most colleges and universities devote considerable resources to academic support, such as tutors, mentors and study hall. Athletes, particularly freshmen, are generally required to participate in these services. Furthermore, advisors typically monitor intercollegiate athlete academic eligibility.

In addition to academic support, some colleges and universities offer counseling and sports psychology services to help students with personal and mental health issues. Unfortunately, as mentioned previously, intercollegiate athletes hesitate to use these optional services (Brewer, Van Raalte, Peptitpas, Bachman, \& Weinhold, 1998; Ferrante, et al., 1996; Watson, 2005). If athletes do seek help, it's often from their coaches, teammates, parents, and friends who are easily accessible and associated with less social stigma but may not be sufficiently trained in areas of mental and physical health (Hinkle,1994; Selby, Weinstein, \& Bird, 1990). Athletic personnel, faculty, and the community need to work collaboratively to make certain intercollegiate athletes receive the appropriate support services to facilitate college adjustment and successfully manage their dual roles. 


\section{Problem Statement}

Although participation in intercollegiate athletics provides various benefits to athletes, the many pressures associated with their dual role puts them at risk for personal and mental health issues for which they are reluctant to seek assistance. Purpose Statement

The purpose of this project was to create a mandatory course to assist freshmen and transfer intercollegiate athletes with academic, athletic, personal and mental health issues as they transition into California State Polytechnic State University, Division I athletics, and the San Luis Obispo community.

\section{Guiding Questions}

The following questions guided the development of this course proposal:

- What specific academic, athletic, personal and psychological issues do intercollegiate athletes face?

- How do intercollegiate athletes perceive themselves? As students, as athletes, or a combination of both?

- How can the university, community, faculty and athletic staff encourage intercollegiate athletes to acknowledge and equally value their roles as students and as athletes?

- How does intercollegiate athlete social identity change over the course of college life?

- What self-management strategies can intercollegiate athletes develop to enhance their academic, athletic, and personal performance? 
- To what extent do intercollegiate athletes utilize the established California Polytechnic State University campus support services?

- What course learning objectives will assist intercollegiate athletes as they attempt to balance their dual roles?

- What instructional methods should be used to assess student learning?

I addressed these questions in light of the Social Identity (Tajifel \& Turner, 1986) and Social Cognitive (Bandura, 1986) Theories. Social Identity Theory discusses the manner in which individuals perceive and categorize themselves. According to this theory, individuals develop their esteem based on both self and collective identity. Self identity refers to distinctive qualities such as our beliefs, skills and abilities. Collective identity involves the qualities we acquire from belonging to a family, culture or group. People who use this theory assume that individuals associate with groups that strengthen their self-esteem.

Social Cognitive Theory is based on the premise that behavior is a function of a continuous and reciprocal interaction between cognitive, behavioral, and environmental variables. According to this theory, individuals respond both proactively and reactively to external influences. The external influences can be modified as a result of an individual's response.

\section{Justification Statement}

Participation in sports offers many benefits to intercollegiate athletes. It does not however, ensure protection from the many academic, social, emotional and psychological pressures that all college students face. In fact, research indicates that intercollegiate athletes may be at more risk as they attempt to balance the 
demands of college with those of athletics (Ferrante, et al., 1996; Hinkle, 1994;

Kimball \& Freysinger, 2003; Murray, 1997; Papanikolaou et al., 2003).

In addition to coping with the challenges facing all students, intercollegiate athletes must fulfill their sports related obligations, as well. They face high expectations to perform athletically, as well as academically. Typically, colleges and universities provide athletes access to many academic support services. Use of these services is usually recommended and monitored by staff advisors and counselors. Some colleges also offer personal and psychological support to help athletes cope with the numerous pressures associated with college and sport. Unfortunately, for various reasons, many intercollegiate athletes ignore or underuse these voluntary support services.

California Polytechnic State University is a highly competitive academic campus with an extremely selective admission process. In fall, 2010, 10,918 freshmen were accepted from an applicant pool of 33,626. The average high school grade point average of that group is 3.9, with an average Scholastic Aptitude Test score of 1292 .

To help student athletes meet their academic requirements, California Polytechnic State University offers the typical academic support services. Tutoring, study hall, seminars, and academic advising assist athletes with their educational requirements. In addition, all new students are invited to attend Student Orientation Advising Registration (SOAR), a one day orientation program, conducted by the Student Life and Leadership staff. To address personal and psychological needs, information on the athletic website directs athletes to campus centers which address 
issues including career, gender identity, mental wellness and career services. Also, mental health information flyers are available in the athletic department.

Sport psychology research indicates that athletes do not automatically obtain important life skills and self-management strategies simply through sport's participation (Shields \& Bredemeier, 1995: Weinberg \& Gould, 1999). According to Gould, Laurer, Collins, and Chung (2002) coaches, instructors and significant others should teach and continually stress life skills to make certain that athletes acquire these essential skills. A mandatory university course serving freshmen and transfer intercollegiate athletes would provide an opportunity to teach important life skills and develop self-management techniques. The course would also serve to increase awareness of the athletes' personal and mental health issues, as well as provide a safe and comfortable forum to address them.

\section{Guiding Principles}

The proposed course is an initial step in the process to address the needs of intercollegiate athletes. University administrators should require additional workshops, seminars, and counseling sessions throughout the college experience to revisit the important issues and concerns presented in the initial transition course.

\section{Limitations}

California Polytechnic State University is located in San Luis Obispo, a fairly small, rural, predominantly white, and middle to upper class community. Therefore, the opinions and perceptions of intercollegiate athletes' difficulties could lack racial/ethnic and class diversity. In addition, access to supplemental community support services may be limited in this small community when compared to a more 
metropolitan area. Furthermore, university budget constraints may limit the course offerings.

Operational Definitions

Athletic identity. The degree to which an individual identifies with his or her athletic role (Brewer, Van Raalte, \& Linder, 1993)

Burnout. A state of physical, mental, and emotional withdrawal that negatively affects self-esteem, purpose, and general attitudes towards sport (Smith, 1986).

Career maturity. The degree to which an individual has achieved developmental tasks, the capacity to formulate plans, and the knowledge and certainty regarding their intended career (Pascarella \& Terenzini, 1991)

Deselection. Occurs when athletes are suddenly excluded from a team based on the decision of someone else (Taylor \& Ogilvie, 1994)

Desocialization. A process of role loss that is accompanied by loss of prestige, social identity, self-esteem, and peer status (Kendall, 2008)

Hegemony. A process of maintaining leadership and control by gaining the consent of other groups, including those who are being led and controlled (Coakley, 2009)

Identity foreclosure. A status attributed to individuals who have committed to roles and beliefs that are usually assigned by others, without taking time to explore the possible alternatives (Marcia, 1966)

Internalization model. A process through which people learn the rules and roles they must know to live in and contribute to society (Coakley, 2009) 
Resocialization. The process of learning different attitudes, values, and behavior from those in a person's background (Kendall, 2008)

Intercollegiate athlete. A college student who is responsible for the educational, social, and emotional challenges experienced by non-athletes, in addition to the challenges related to sport (Watt \& Moore, 2001)

Intercollegiate athlete academic services. Services which include academic advising, tutoring, academic mentoring, goal setting, time management, note-taking, and study hall

Intercollegiate athlete supplementary support services. Services related to career choice, nutrition, substance abuse, sexual responsibility, ethical conduct, diversity, group dynamics, role identity, sport psychology, social relationships, selfidentity, personal growth and emotional well-being 


\section{Chapter 2}

\section{Literature Review}

\section{Introduction}

The purpose of this project was to create a mandatory course to assist freshmen and transfer intercollegiate athletes as they transition into California Polytechnic State University, Division 1 athletics, and the San Luis Obispo community. The first section of this chapter provides an overview of intercollegiate sports and its historical relationship with higher education. This historic context will enable university administrators, faculty, and coaches to recognize the role conflict that intercollegiate athletes experience. The next section offers various reasons why people become involved in sports as well as their motives for desocialization and resocialization. The following section discusses the Social Identity and Social Cognitive Theories which contribute to a better understanding of the way intercollegiate athletes perceive and categorize themselves, and how their behavior influences their thoughts and actions. The next section addresses the concept of culture shock and the social and psychological issues and challenges facing intercollegiate athletes. Subsequently, the barriers and obstacles which cause intercollegiate athletes to underuse campus support services are outlined. The final sections summarize similar course offerings from selected NCAA programs and discuss the value of self-management strategies for improving performance. Evolution of Intercollegiate Sports in the United States

An awareness of the evolution of intercollegiate sports in the United States provides a framework to better understand the relationship between intercollegiate athletes and the educational system. The athletic-academic relationship in the college environment 
has traditionally been problematic. This historical framework may also contribute to a better understanding of the current issues and controversies in sport and how they impact intercollegiate athletes.

Sport in the $19^{\text {th }}$ century. In the early $19^{\text {th }}$ century, administrators in American colleges did not encourage athletics, considering them inconsequential and antiintellectual activities. Male students organized and sponsored all university athletic activities. They established the rules, arranged travel, and administered the athletic program without interference from coaches, trainers or college administrators (Gerdy, 2002; Horowitz, 1987). Female students participated in intramural, club, and sorority events under the direction of women physical educators. Their events were noncompetitive, informal and without rules (Hult, 1994). At this time, college athletic activities for both males and females served as enjoyable diversions but played a minor role in the life of students (Gerdy, 2002).

By the mid $19^{\text {th }}$ century, competitive intercollegiate sports were introduced into United States colleges and universities. The first men's intercollegiate event, a crew contest between Harvard and Yale, led to the formation of additional crew teams (Gerdy, 2002; Zimbalist, 1999). During the following 25 years, men's intercollegiate baseball, track \& field, rugby, soccer and football teams emerged.

The first female intercollegiate event occurred in 1896 when the University of Berkeley played Stanford and the University of Washington played Ellensburg Normal School in basketball. Following these events, females from other colleges demanded participation in intercollegiate events. During the next few years, competition for college females increased slightly but it was opposed by physical educators who were not ready 
to lose control over women's athletics as they thought men had (Gerber, Felshin, Berlin, \& Wyrick, 1974). As a result, females enjoyed limited competitive opportunities well into the $20^{\text {th }}$ century (Hult, 1994).

Toward the end of the $19^{\text {th }}$ century, men's intercollegiate sports, particularly football, enjoyed an increasingly important role on college and university campuses. Games, no longer considered pleasurable diversions, became competitive events focused on winning. This win-at-all-costs attitude created temptation to recruit the best male athletes with little regard to academic status (Gerdy, 2002; Hawes, 1999).

Gerdy (2002) describes how the popularity of football continued into the $20^{\text {th }}$ century. Newspapers, radio, newsreels and magazines contributed to this popularity by portraying male athletes as heroes on and off the field. Winning teams enjoyed abundant spectators, increased revenue, media coverage and public attention, making football a lucrative business. Successful male programs became sources of community pride. As a result, college and university administrators began to incorporate athletics into the institution's educational mission.

The desire for championship teams, led to unregulated recruiting, issues of eligibility and inequitable resources available to the institutions and their athletes. Violence increased on the football field leading to serious injuries and deaths. As a result of these concerns, in 1906, the National Collegiate Athletic Association (NCAA) was created to establish rules and oversee intercollegiate sports in the United States. Unfortunately, it was difficult for the NCAA to enforce their rules due to the dominance of coaches and athletic directors (Hawes, 1999). 
Sport in the $20^{\text {th }}$ century. At the turn of the century, some people developed new ideas about sports believing "they could be used as tools for changing behavior, shaping character, creating national loyalty and training workers to use teamwork as a tool for being more productive" (Coakley, 2009, 72). Unfortunately, the new ideas, intended primarily for white males, did not apply to women, Blacks or white ethnics who continued to experience very limited and/or segregated sports participation at this time.

In 1929, the Carnegie Foundation for the Advancement of Teaching published a report by Howard Savage (1929) that identified numerous problems in college sports. Results indicated that just 28 of 112 colleges operated ethical athletic programs. Savage (1929) called for the reform of American college athletics stating that the relationship between intercollegiate sports and the academic institution had become strained. He questioned whether a university could adequately promote intellectual development while securing and developing winning teams (Gerdy, 2002; Watt \& Moore, 2001).

Soon after Savage (1929) published his report, a large group of women's physical educators met to organize female intercollegiate sports. According to Park and Hult (1993), they were determined to keep athletics in an educational environment for women thereby avoiding some of the problems associated with male intercollegiate sports. At that meeting, the physical educators established the Women's DivisionNational Amateur Athletic Federation (NAAF) to promote the integrity of female intercollegiate sports. The NAAF was one of many organization developed to promote the integrity of women's sports. 
Intercollegiate sports opportunities for women improved by the mid $20^{\text {th }}$ century due to several historical events. World War II provided women, who joined the military, the opportunity to show they could successfully compete in the workforce and therefore on the athletic field. The passage of the Civil Rights Act of 1964 which improved the status of women and minorities, led to national discussions about equal rights and greater athletic opportunities for collegiate women (Gelb \& Palley, 1996). In 1972, the landmark Title IX legislation which prohibited gender discrimination in educational programs increased female intercollegiate sport participation substantially.

After World War II, university and athletic enrollment increased. Commercial radio, the press and film industry continued to popularize sports which had become a billion dollar business. With popularity, came accusations of gambling, improper recruiting, lack of academic standards, and financial aid infractions (Zimbalist, 1999). As a result of these allegations, in 1946, the NCAA adopted the "Principles of Conduct of Intercollegiate Athletes" which was one of many policies intended to address the concerns regarding intercollegiate sports. The "Principles of Conduct", renamed the "Sanity Code", did not fix the problems but led to the growth of NCAA enforcement (Brown, 1999). Since its inception, the NCAA has instituted several other landmark decisions to improve the lives of intercollegiate athletes.

By the mid $20^{\text {th }}$ century, television further popularized intercollegiate sports which promoted the entertainment value rather than the needs of athletes or the university. Cultural values also led to significant changes in sports policies. Athletic scholarships, typically awarded to traditional revenue sports, were awarded to athletes in minor sports such as track, soccer, baseball and swimming. Females demanded equal treatment in 
terms of programs and scholarships, as well (Hawes, 1999). In addition, the number of multisport athletes dwindled as sports specialization increased.

Modern day sport. Since their modest beginnings in the mid $19^{\text {th }}$ century, intercollegiate athletics in the United States have become an inherent part of the education system. Modern day collegiate sport represents an industry and an identity that serves many conflicting interests. Intercollegiate athletes now represent a diverse group of men and women on college campuses in terms of personal history, academic background, life goals, physical and psychological skills and developmental readiness (Etzel \& Pinkney, 2002).

Despite the reform instituted in the last century, questions linger about intercollegiate athletes' well-being. Many concerns noted in the 1929 Carnegie Foundation report remain evident today. Watt and Moore (2001) pose an important question: "As intercollegiate athletics become more and more commercial and are increasingly viewed as a form of mass entertainment, how can colleges and universities protect the integrity of their academic mission and the intellectual environment while allowing student athletes to reap the benefits that both roles-student and athlete- provide?" Socialization into Sport

What draws people to actively participate in sport? Socialization is a complex, interactive process by which individuals acquire the norms, customs, and ideologies that are suitable to their position in society. According to Coakley (2007) socialization into sport takes place in conjunction with the overall socialization process in our lives. This decision is inspired by the available opportunities, the presence of social support, the 
development of identity formation, and the cultural framework in which the decision is made.

Sport sociologists have studied the process of becoming involved in sports for over fifty years. Most scholarly work involving sports and society uses one, or a combination of five major social theories - Functionalist Theory, Conflict Theory, Interactionist Theory, Critical Theory, and Feminist Theory. Theories influence people to make better decisions, see sports from different angles, and recognize the relationship between sports and social life (Coakley, 2007). The following paragraphs provide an overview of how scholars study socialization into sport.

Functionalists view society as an organized system of interrelated parts in which each part is dependent on the other in order to function. Sports are studied in terms of what they contribute to society. Functionalists utilize Coakley's (1992) internalization model for socialization. In this model, individuals learn the rules and roles they must follow, through the influence of families, teachers, coaches and peers. Coakley (2007) refers to these significant others as "agents of change". Functionalist research focuses on sport participation and positives outcomes for individuals. Lever (1983), for example, examined the impact of football in Brazilian society. She found that Brazilian football exemplifies a key functionalist belief that spectator sports bring people together.

Conflict theory is based on the assumption that society is a system of structures and relationships shaped by economic factors. Sports are studied in terms of how they promote money, wealth and economic power. Conflict theorists also look at socialization in light of the internalization model (Coakley, 1992) but their research focuses on how sports perpetuate the power and privilege of elite groups in society. For 
instance, Rigauer (1981) studied the relationship between sports and capitalism. He explored the idea that sport is work and athletes are commodities to be bought and sold.

Functionist and Conflict theorists suggest that participation in sport is associated with the following factors: an individual's abilities, characteristics, and resources; the influence of socialization agents including parents, teachers, peers and role models; and, the opportunities that are accessible and personally rewarding.

Interactionists assume that society is created and sustained through social interaction. They study the way sports are created and given meaning by the people who participate. According to this theory, sports participation involves a process of ongoing decision-making influenced by social and cultural perspectives. Stevenson (1999) found that people are introduced to sport through their interactions with significant others. Gradually, they become involved in a sport that promises success and provides a link to the people involved with that sport. The decisions people make about sports change as social conditions change (Coakley \& White, 1999; Stevenson, 1999). Research is based on the experiences of athletes and how they develop meaning and identity related to their participation. In light of the Interactionist Theory, Donnelly and Young (1988) studied the complex process of socialization into the sport subcultures of rugby and mountain climbing. They found the process involves acquiring knowledge about the sport, associating with established team members, learning the sport norms, earning acceptance, and finally being confirmed as a member of the team.

Critical theorists assume that society involves cultural production, power and social relations that either empower or suppress individuals and groups (Coakley, 2007). 
They believe that people construct sports, day by day, as they interact with one another. Researchers focus on the meaning and organization of sports, as well as the opportunity for cultural transformation. Foley (1990) explored the perception that sport in a small Texas town offers the opportunity to reduce hegemonic cultural practices. He found that sport provided important community rituals, however it also perpetuated existing gender, race, ethnic, and income discrimination.

According to Feminist Theory, society is persistently gendered. Sports are seen as activities that devalue, exploit, and oppress females. At the same time, sports are organized by powerful and influential men who present distorted views about masculinity. Researchers investigate how sports reproduce gendered ideas and the need to better represent female perspectives in society. In light of the Feminist Theory, Birrel (2000) found that modern organized sports are gendered activities with value and power related to masculine traits. Also reflective of Feminist Theory, Hannon, Soohoo, Reel, and Ratliffe (2010) found that high school students, despite their ethnicity, expressed conventional gender ideologies. The students reported that males and females should participate in sports based on the physicality of the activity.

Social theories contribute to our knowledge of the various societal perspectives regarding sports involvement. Using one theory or a combination of theories enables us to identify and understand many of the problems that intercollegiate athletes face as they engage in sport.

\section{Socialization out of sport}

What causes athletic careers to end? Taylor and Ogilvie (1994) proposed a conceptual model which recognizes four major causes for career termination- age, 
deselection, injury, and free choice. To achieve healthy career transition, athletes must utilize appropriate resources to negotiate many psychological, social, financial, and occupational issues. When athletes fail to manage these issues, they risk psychopathology, substance abuse, occupational, family and social problems (Taylor \& Ogilvie, 1994).

Free choice. Free choice is the ideal reason for socialization out of sport (Taylor \& Wilson, 2005). Athletes who choose to terminate their career generally have successful transition to new careers (Coakley, 1983; Taylor \& Ogilvie, 1994) and a healthy selfidentity (Grove, Lavallee, \& Gordon, 1997). In addition to free choice, having a balanced self-identity, maintaining satisfying relationships, and planning for desocialization contribute to successful transition (Levy \& Gordon, 2005).

Involuntary termination. Involuntary termination is difficult with injuries causing the most adjustment problems (Webb, Nasco, Riley, \& Headrick, 1998) especially for those who primarily identify with their athletic identity (Brewer, 1994; Brewer, Van Raalte, \& Petitpas, 2000). Age is the most frequent cause for socialization out of sport (Ogilvie \& Taylor, 1993). Deselection due to poor performance is also difficult, causing athletes to feel angry, unsupported, and unsure about their future (Ogilvie \& Taylor, 1993; Sinclair \& Hackfort, 2000).

Athletic burnout. Athletic burnout is a complex issue that also causes athletes to socialize out of sport. Researchers do not agree on a single definition of burnout, but there are several accepted definitions that all acknowledge the psychological, emotional, and physical components that cause athletes to withdraw. Some researchers consider stress as the primary cause of burnout (Silva, 1990; Smith, 1986) 
while others believe it is due to an imbalance between costs and benefits (Raedeke, 1997; Schmidt \& Stein, 1991) or by a desire for personal control (Coakley, 1992). Life after Sport

Termination of an athletic career is an inevitable but often a distressing milestone for athletes. They are frequently unmotivated, psychologically distressed and vocationally unprepared (Levy \& Gordon, 2005). Fortunately, many of the qualities developed and nurtured through intercollegiate sports participation contributes to successful career transition. According to Figler and Figler (1991) athletes gain valuable skills that extend beyond the playing field. Skills gained as an athlete include physical and mental alertness, endurance and persistence, goal directedness, ability to work well with others, loyalty to and support of group goals, resilience, and ability to organized time (Figler \& Figler, 1991). Likewise, Bisconti and Kessler (1980) found that athletic participation promotes career development in areas of competitiveness, teamwork, interpersonal and leadership skills.

While many athletes successfully transition out of sport, others face problems such as identity foreclosure and social isolation (Shurts \& Shoffner, 2004) or loss of control, anger, limited coping skills and uncertainty about the future (Ogilvie \& Taylor, 1993; Sinclair \& Hackfort, 2000). Some athletes in revenue-producing sports reportedly have lower levels of career maturity (Blann, 1985; Kennedy \& Domick, 1987).

The Social Identity Theory

Social Identity Theory (Tajifel \& Turner, 1986) is a general theoretical approach that asserts a person's identification with a group can be an important facet of their self concept. The core idea is that people tend to search for and participate in groups that 
affirm their self esteem. To achieve distinctiveness, people must believe they are in the right or "in" group.

Tajifel and Turner (1986) found that people have the natural tendency to categorize themselves into multiple groups. The component of a person's identity that is most dominant changes depending on the group they are associating with. For instance, an intercollegiate athlete can be categorized as a student, an athlete, and a female. When the "athlete" is with her team, she may feel that the athletic part of her identity is dominant which confirms her "in" group identity. On the other hand, the "student" aspect of her identity is dominant when she is among other students in the classroom.

Social Identity Theory (Tajifel \& Turner, 1986) assumes that most freshmen intercollegiate athletes should identify with the socially desirable dual status of student and athlete, thereby giving them a sense of self-worth. Similarly, Chandler and Goldberg (1990) found that most high school male athletes choose to be remembered as scholar-athletes as opposed to simply talented athletes, so their desire to achieve this standing as college athletes becomes a valued identity. Marx, Huffman, and Doyle (2008) also found that student athletes enter college with a high level of optimism in their ability to maintain their dual roles. In their study, female commitment to both roles grew stronger over time, while males' commitment decreased.

Killeya-Jones (2005) found that intercollegiate athletes who consider themselves as students as well as athletes gain academic and psychological advantages. Specifically, they found that elite football players who regarded academics as highly as athletics, tended to experience academic and personal gratification. In contrast, the football players who valued athletics over academics were more likely to experience elevated 
levels of depression and decreased self-esteem. Marx, et al. (2008) found that athletes who most strongly commit themselves to their peers and their group efforts often find it very difficult to develop a balanced student athlete identity because academic demands run counter to the team's best interest

Intercollegiate athletes have the opportunity to gain esteem from identification as a student and as an athlete. According to researchers, all dual social identities are susceptible to shatter if either role significantly enhances or damages self esteem. They go on to say that intercollegiate sports have the potential to do just that (Marx, et al., 2008).

Social Cognitive Theory

One extensively used and empirically validated theory that explains the effectiveness of self-management training is Social Cognitive Theory (Bandura, 1986). Social Cognitive Theory provides a framework for understanding, predicting, and changing human behavior. The theory identifies human behavior as an interaction of personal factors, behavior, and the environment (Bandura 1986). Two social cognitive theory constructs that may underlie the effectiveness of self-management training are selfefficacy and outcome expectations (Frayne \& Geringer, 2000).

Self-efficacy relates to a person's judgments about his or her competence to organize and perform specific courses of action that will be necessary to achieve a designated type of performance (Bandura, 1986). Self-efficacy is a principal motivational construct that influences goal level, as well as goal commitment. It influences an individual's choices about which behaviors to assume, how much energy 
to use, how long to persevere in their efforts to overcome the difficulties that are encountered in the undertaking, and eventually a person's performance.

Outcome expectancies represent beliefs concerning short and long term consequences of behavior. In other words, there is the expectation that specific outcomes tend to follow a given action. Like self-efficacy, outcome expectations are specific to a certain task or circumstance, as opposed to being generalized expectancies about self and system. Bandura (1986) maintains that individuals were more likely to act on their self-percepts of efficacy and assume behaviors when they believed that their action would result in valued outcomes rather than when their behaviors were expected to produce outcomes that the individual did not regard as having a beneficial outcome. When individuals believe that they can perform a specific task in a competent manner but that someone in their environment, such as a supervisor or instructor, will be unresponsive to their improved performance, they are unlikely to change their behavior (Frayne \& Geringer, 2000). Social and Psychological Issues and Challenges

Intercollegiate student athletes face a unique set of social and psychological issues and challenges which necessitate the need for sufficient coping skills and selfmanagement strategies. Some of the social and structural challenges most commonly addressed in research are balancing athletics and academics; adapting to social changes; managing athletic successes and failures; minimizing physical injuries; terminating athletic careers; and managing weight issues (Papanikolaou, et al., 2003; Watson, 2002). Division classification, gender, race, ability, and sport further impacts these challenges (Street, 1999). 
In addition, athletes, like all college students, may experience culture shock, the emotional and sometimes physical discomfort individuals feel when immersed in a new culture with a different way of life and a different mindset. Typically, students enter college feeling excited and ready for a new adventure. Sometimes, however the initial euphoria is replaced with a sense of confusion, uncertainty, and feelings of anxiety related to homesickness, perceived inadequacy, and loneliness because their cultural and social ideas that may not be consistent with their new environment.

Adjusting to college is an ongoing and gradual process. Feelings of culture shock are normal but the extent of the change and the effect it has on a person is often surprising, stressful, and overwhelming. As intercollegiate athletes face the personal and environmental pressures related to these challenges, they often resort to poor coping strategies which increase their risk for social and psychological problems such as mental health disorders, eating disorders and substance-related disorders (Watson, 2002).

Mental health disorders. Intercollegiate athletes are at risk for many mood and anxiety disorders (Humphrey, Yow \& Bowden, 2000) including depression and suicide (Baum, 2005; Brewer \& Petrie, 1996; Murray, 1997) stress and low self-esteem (Hudd et al. 2000; Murray, 1997; Papanikolaou, et al., 2003; Raedeke, 1997) and psychological problems (Baum, 2005; Shirka, 1997). According to Humphrey et al., (2000) nearly $50 \%$ of males and more than $50 \%$ of females reported that stress from athletic participation significantly affected their mental or emotional health. Similarly, Carr (2007) found the prevalence of depression (21\%) in female college athletes to be 
slightly higher that a national sample and anxiety in the female athletes (33\%) was significantly higher than the non- collegiate athlete national sample (8\%).

Eating disorders. Eating disorders are a significant public health problem, affecting several million individuals. Athletes may have a higher incidence than the general population due to the pressures of sports competition. The prevalence of eating disorders among athletes, particularly females, appears more widespread with researchers finding that $9 \%$ of female collegiate Division I athletes need treatment for disordered eating (Johnson, Powers, \& Dick, 1999). Females in all sports are subject to disordered eating but research indicates that females in sports than emphasize thinness such as swimming, gymnastics, and cheerleading are most at risk (Smolak, et al., 2000; Torstveit \& Sundgot-Borgen, 2005). Some researchers found that white female athletes report stronger motivation for thinness, body dissatisfaction, and disordered eating behaviors than Black female athletes (Johnson, Crosby, Engel, Mitchell, Powers, Wittrock, \& Wonderlich, 2004). Male athletes, especially distance runners, rowers, boxers and wrestlers, also suffer from disordered eating but research is limited in this area (Beals \& Manroe, 2000). Results from a NCAA Division 1 study of male and female athletes, indicated that 13 percent showed clinical signs of disordered eating (Johnson et al., 1999). Some researchers report that disordered eating declines when athletes are out of season (O'Connor, 1996) however the concern remains that some athletes may develop life-long medical problems (Williams, 2007).

Substance-related disorders. Intercollegiate athletes are at high risk for substancerelated disorders (Martens, Dams-O'Connor \& Beck, 2006; NCAA, 2005; Watson, 2002). Athletes use various substances to alter their mood and cope with many 
psychological symptoms (Miller, Miller, Verhegge, Linville, \& Pumariega, 2002) but alcohol is much more frequently used than other drugs (Selby, et al., 1990; Thombs, 2000). Researchers in a NCAA study (2005) found that more than $75 \%$ of intercollegiate athletes surveyed admitted to alcohol use within the previous year, often drinking 6 to10 drinks or more in one sitting. Marijuana is another popular drug among athletes (Inaba \& Cohen, 1994). According to a national survey conducted in 2001, $27 \%$ of all intercollegiate athletes used marijuana while in school (Higher Education Center, 2003). In addition, the NCAA (2005) found that $20 \%$ of intercollegiate athletes reported marijuana use during the previous year.

Underuse of Support Services

Many college administrators, educators, and athletic personnel recognize the many social and psychological challenges facing intercollegiate athletics, and offer a variety of resources and services to assist athletes. However, intercollegiate athletes tend to avoid or underuse these support services (Brewer \& Petrie, 1996; Ferraro \& Rush, 2000; Murray, 1997; Pinkerton, Hinz \& Barrow, 1989; Watson, 2005) preferring to seek help from coaches, teammates, friends and family (Selby, et al., 1990). Researchers find there are several reasons for this under-use of support services.

\section{Barriers and Obstacles to Using Support Services}

Internal barriers. Several personal obstacles limit intercollegiate athletes' use of support services. College athletes are generally popular, highly visible students who are often considered heroes on campus. To be seen at the counseling or mental wellness center would jeopardize this image (Etzel, Ferrante \& Pinkney, 1991). In 
addition, many intercollegiate athletes reluctantly acknowledge personal weaknesses for fear it would reflect negatively on their ability to perform (Watson, 2003).

External barriers. Intercollegiate athletes also face external obstacles that dissuade them from using support services. Team commitments decrease the amount of time necessary to access available services. In addition, many athletic departments encourage athletes to share their problems with the coaches, trainers, and teammates rather than use campus services (Ferrante, et al., 1996). Further, some university administrators fear the perception that intercollegiate athletes already enjoy too many privileges. Administrators are also concerned about disrupting programs that are successful or involving themselves with programs that are unsuccessful (Etzel et al., 1991). Thus support services are available but the athletes often do not benefit from them.

\section{NCAA CHAMPS/Life Skills Program}

In 1994, the NCAA launched the CHAMPS/Life Skills Program designed to support the total development of student athletes. The program includes academic, athletic, personal, career, and service components. To qualify for membership, institutions must designate a Life Skills Coordinator who must attend an annual orientation workshop or an orientation conference the year of admission. Membership is free but the institution is responsible for funding the program. The NCAA provides materials, resources, and program models but it is up to the participating institutions to structure the program to fit the need of their intercollegiate athlete population. There are currently 664 Division I, II, and III institutions participating in the CHAMPS/Life Skills program. California Polytechnic State University is listed on the NCAA CHAMPS/Life Skills website. 
CHAMPS/Life skills syllabi. Several NCAA institutions offer courses to address the needs of freshmen and transfer intercollegiate athletes, while others are available to all athletes. After review of 30 examples of class syllabi for CHAMPS/Life Skills program classes, I found that instructors used most class sessions to discuss academic issues and fewest sessions to discuss sport psychology, sport socialization, role identity, and body language. The percentage of time involved teaching specific topics is as follows: academics, $22 \%$; ethical conduct, 13\%; personal health, including substance abuse and sexual responsibility, 13\%; career planning, 9\%; NCAA rules and transition to college, 9\%; diversity, 7\%; nutrition, 5\%; stress, 5\%; group dynamics, 5\%; financial issues, $4 \%$; community service, $3 \%$; sport psychology, $2 \%$; sport socialization, role identity and body language in sport, $3 \%$.

The CHAMPS/Life Skills program provides a general framework to address many important topics and issues however it tends to be a generic program. It does not address the specific needs of California Polytechnic State University intercollegiate athletes. In addition, I have found no evidence that this program is based on research. It is my hope to utilize specific features of the NCAA CHAMPS/Life Skills program to create a theory based self-management program for improving student and athletic performance.

Self-management Training

Self-management can be viewed as a set of behavioral and cognitive strategies that assist individuals in structuring their environment, establishing self-motivation, and facilitating behaviors appropriate for attaining performance standards (Manz, 1986). 
One approach to controlling behavior in organizations is through the external application of control mechanisms to influence individuals toward organizational goals. In contrast, self-management is an effort by an individual to exert control over certain aspects of his or her own decision making and behavior.

In a field experiment, Frayne and Geringer (2000) investigated the effectiveness of a theory based self-management training program for improving job performance of individuals, specifically the performance of life insurance salespeople. The results are fairly conclusive that self-management training had profound effects on all measures in this study. Self-management by salespeople successfully changed the specific behaviors targeted in the training resulting in increased performance that continued over time. In addition, both self-efficacy and outcome expectancies were highly related to job performance. This finding is in accord with self-efficacy theory (Bandura, 1997b) which states that both self-efficacy and outcome expectancies are important cognitive influences on an individual's motivation and subsequent task performance.

Everyone practices self-management, however not everyone is an effective selfmanager, and some individuals may engage in dysfunctional self-management (Karoly, 1993). Since self-management is a learned behavior, there is an opportunity for enhancing individual performance through self-management training (Frayne \& Geringer, 2000).

In 1993, Judy Stephen, an instructor at the University of Arkansas, developed a course to fulfill NCAA life skills requirements for freshmen student athletes. Over the years, her course evolved from a standard textbook lecture course into a critical examination of selected academic and sports issues with a focus on goal setting and 
the development of self-management skills to guide decision making. According to Stephen, the self-management piece contributed significantly to changing and/or shaping desired behavior.

\section{Summary}

Since the first intercollegiate event in the mid $19^{\text {th }}$ century, college sports have become increasingly important in our society. During those years, the relationship between athletics and higher education has often been tumultuous. Questions have arisen regarding the welfare of the intercollegiate athlete and his or her ability to balance daily life in order to get the most out of both athletics and academics. University officials, along with the NCAA, have instituted athletic reform to help improve the lives and experiences of intercollegiate athletes. Yet, researchers find that athletes continue to face a unique set of challenges that they are often unable to meet. Furthermore, intercollegiate athletes tend to avoid or underuse available campus support services. Without assistance, a number of these athletes experience personal and mental health issues as they try to balance both their academic mission and their athletic goals. A mandatory course would provide valuable knowledge, skills, and selfmanagement tools to assist freshmen and transfer intercollegiate athletes with successful transition into, through, and beyond college life. 


\section{Chapter 3}

Methods and Procedure

\section{Course Purpose}

The proposed course is designed to provide the opportunity for California Polytechnic State University intercollegiate athletes' to acquire the knowledge and skills necessary to improve their personal effectiveness as both students and athletes. A theory-based self-management training program will provide athletes with behavioral and cognitive strategies intended to structure their environment, establish selfmotivation, and facilitate behaviors appropriate to promote a healthy adaptation to the specific demands of their dual role.

\section{Gathering Resources for Course Content}

A variety of resources were used to facilitate the development of the proposed course. Data collection includes an interview with Shannon Stephens, Cal Poly Director of Academic Services; email and phone conversations with various athletic directors and Cal Poly alumni; informal discussions with current intercollegiate athletes and athletic coaches; an assessment of Cal Poly campus academic and supplemental support services; a review of NCAA Champs Life Skills materials; and a review of selected Division 1 and 2 university syllabi. Current and former life skills instructors including Judy Stephen, University of Arkansas; John Hamilton, Ph. D., University of California, Los Angeles; Joe Luckey, Ph. D., University of Memphis; Sandy Meyer, Penn State University; and, Derek Van Rheenen, Ph. D., University of California, Berkeley were contacted. In addition, the following researchers discussed their findings: Sherry 
Watt, Ph. D., Joshua C. Watson, Ph. D., University of Mississippi, Meridian Campus, and, Colette Frayne, California Polytechnic State University. Furthermore, several recommendations emerged from the literature review.

\section{Course Structure}

The course is structured, based on research and personal correspondence, to include lectures, small group discussions, and one-on-one meetings. The class sessions include the following: self-management principles; self-assessment of one's own behavior; establishment of self-set goals; self-monitoring of the target behaviors; self-evaluation strategies; writing of behavioral contracts; and maintenance strategies for continued success. The theoretical rationale for combining these variables within a self-management program can be found in Bandura (1977b) and Frayne and Geringer (2000) and Frayne and Latham (1987).

Course Outcomes, Objectives, and Assessment

Outcome 1: Create a self management tool kit which contains a set of behaviors and cognitive strategies that assist intercollegiate athletes in structuring their environment, establishing self-motivation, and facilitating behavior appropriate for successful behavior Objectives:

- Assess and identify personal, athletic, and academic target behaviors

- Establish short and long term goals based on the behaviors identified in the self assessment

- Develop a system to monitor and evaluate progress toward goals 
Assessment:

Create a self-management portfolio that includes the target behaviors, goals, monitoring and evaluation systems, behavioral contract, and reflective essay

Outcome 2: Create a broad-based set of skills and knowledge combined with unique social experiences that will facilitate growth in each intercollegiate athlete's global selfconcept

Objectives:

- Examine intercollegiate athlete academic and athletic role identities to determine how they may change over the course of the college experience

- Compose an autobiography

- Compare and contrast the attributes of successful students and athletes

- Establish heterogeneous learning teams led by selected mentors to discuss methods to broaden one's identity

Assessment:

Group presentation: How to be successful in academics, athletics and life

Outcome 3: Design a contingency plan to be implemented when faced with personal, social, and psychological diversity

Objectives:

- List potential academic, athletic, and personal challenges that intercollegiate athletes experience

- Assess available campus and community support services

- Investigate intercollegiate athlete resistance toward the utilization of support services 


\section{Assessment:}

Case studies specific to identified issues; Create a collective portfolio

Outcome 4: Specify a plan for successful transition out of sport and create a personal career plan

Objectives:

- Identify the challenges related to transition out of sport

- Identify the characteristics and skills of intercollegiate athletes that are transferable to the working world

Assessment:

Create a resume; Reflection paper

Course Topics

The course topics relate to current issues and challenges relevant to intercollegiate athletics and supported by research. Topics include role identity; social and psychological issues including mood and anxiety disorders, disordered eating, substance abuse; goal setting; career transition; sport socialization; time management; sport psychology; diversity; group dynamics; community service; community and university resources.

Course Requirements and Activities Description

- Self- Management Dimension: Systematic data gathering about the behaviors the individual wishes to improve or modify. This activity will provide the learner with a means of interpreting and changing his or her own behavior. 
- Goal Setting: On the basis of the behaviors identified during self-assessment, individual establishes goals (short and long-term). This will provide direction for the individual efforts, avoiding what might otherwise be sporadic, reactionary activity lacking a consistent, purposeful basis.

- Self Monitoring: Process by which the individual maintains a record of his or her progress toward goal attainment. This process will provide the learner with data regarding progress toward attainment of his or her self set goals. These data subsequently will become the basis for self evaluation.

- Self Evaluation: The use of self-reinforcement and self-punishment strategies on the basis of the individual's performance relative to his or her self set goals. By providing rewards for achieving the individual's goals, a positive influence on future actions can be exerted. Use of self-administered punishers attempts to reduce the incidence of undesired behaviors.

- Written Contracts: A written agreement with oneself that specifies expectations, plans, and contingents for behavior to be changed. The contract is a precursor to administration of the self management program; it will prompt the individual to follow through on the planned course of action and serves as an additional goal commitment.

- Maintenance and relapse prevention: This training will enable the individual to identify common problems and pitfalls in effectively applying self-management techniques to develop procedures for overcoming these circumstances. Having the individual identify high-risk situations that may cause the individual to stop engaging in self-managing behavior can help prevent relapses by helping the 
individual to learn to recognize and avoid or overcome these potential drawbacks.

- Campus cultural event: Attend one campus event and write an account of the experience. Include the following information - date of the experience, reason for selecting the event, a 1 page summary of the event, and your reaction to the experience. Attach an event program, ticket stub, or other attendance confirmation, if applicable. Options include a play, a concert, a multicultural event, a lecture, or other similar event.

- Campus resources team project: With your team, visit a campus support service. As a group, prepare a 5-10 minute oral presentation about the resource. Provide a general overview and details of key services.

- Athletic event: Attend one Cal Poly athletic event that is not your own. Write a brief 2 paragraph description of the event and the outcome. Attach a program or ticket stub, if applicable.

- Community service project: Complete 6 community service hours at an institution or event of your choice. Options include institutions such as hospitals, schools, churches, women's shelters, homeless shelter, retirement homes, or events such as Special Olympics and Read Across America. Write a 1 page summary of your experience. 


\section{Chapter 4}

\section{Conclusion}

The purpose of this project was to create a mandatory course which incorporates a self-management training program to assist freshmen and transfer intercollegiate athletes with academic, athletic, personal, and mental health issues as they transition into California Polytechnic State University, Division I athletics, and the San Luis Obispo community.

The course is designed to promote understanding of the way intercollegiate athletics figures into the overall mission of the university. The course serves to facilitate the understanding and importance of the multiple and often conflicting identities of intercollegiate athletes. Further, it provides an opportunity for athletes to learn about and manage their behaviors as they encounter the various developmental tasks associated with college. Particular areas of focus are academic topics such as time management and utilization of campus academic resources; athletic topics such as teamwork and group cohesion, managing stress and injuries, dealing with slumps and poor performance, and retirement; personal topics such as stress management, making smart choices, interpersonal relationships, the importance of seeking help, and handling public scrutiny.

Personal Reflection

As a former Division I student athlete, I engaged in many athletic and educational endeavors which provided very positive and lasting effects. In addition to the joys, however, I encountered problems similar to those reported in literature. I recall the uncertainty of arriving in an unfamiliar community, thousands of miles from home, 
knowing no one but the coach who recruited me. I experienced periods of "culture shock" including feelings of stress, anxiety, fatigue, and uncertainty related to my student and athletic roles. Furthermore, during my last season, I suffered a career ending injury that left me wondering about my future. Fortunately, my coach and two faculty members with whom I formed close relationships encouraged me to indentify new goals and develop strategies to attain those goals.

Currently, I coach at the Division I level. Each day, I interact with young men who are vulnerable to the many academic, athletic, personal, and mental health issues related to their role as an intercollegiate athlete. It is my hope that the proposed course will serve to help college athletes achieve their academic, athletic and personal goals while at California Polytechnic State University. In addition, I hope the course promotes conversation among coaches, faculty, and athletic administration regarding the various needs of intercollegiate athletes.

\section{Suggestions for Future Research}

Future research might investigate the impact that existing college transition courses have on intercollegiate athlete success as evidenced by grade point averages, hours earned, graduation rates, successful career transition, and self report. In addition, further research might examine the adjustment problems of intercollegiate athletes by gender, race, and/or ethnicity. Finally, researchers could investigate the role of support services as they relate to intercollegiate athletes' academic, athletic, personal, and mental adjustment to college, especially the use of these services and the apparent satisfaction with them. 


\section{References}

Adler, P. A., \& Adler, P. (1991). Backboards and blackboards: College athletes and role engulfment. New York: Columbia University Press.

Bandura, A. (1977). Social learning theory, Englewood Cliffs, NJ: Prentice Hall.

Bandura, A. (1986). Social foundations of thought and action: A social cognitive theory. Englewood Cliffs, NJ: Prentice Hall.

Baum, A. L. (2005). Suicide in athletes: A review and commentary. Clinics in Sports Medicine, 24(4), 853-869.

Beals, K., \& Manroe, M. (2000). Behavioral, psychological, and physical characteristics of female athletes with subclinical eating disorders. International Journal of Sports Nutrition and Exercise Metabolism, 10, 128-143.

Bentley, H. W., McGovern, J. T., Savage, H. J., \& Smiley, D. F. (1929). American College Athletics. New York: Carnegie Foundation for the Advancement of Teaching.

Birrel, S. (2000). Feminist theories for sport. In J. Coakley \& E. Dunning (Eds.), Handbook of Sports Studies. London: Sage Publications, 61-76.

Bisconti, A., \& Kessler, J. (1980). College and other stepping stones: A study of learning experiences that contribute to effective performance in early and long-run jobs. Bethlehem, PA: CPC Foundation.

Blann, F. W. (1985). Intercollegiate athletic competition and students' educational and career plans. Journal of College Student Personnel, 26(2), 115-118.

Brewer, B. W., Van Raalte, J. L., \& Linder, D. E. (1993). Athletic identity: Hercules' muscles or Achilles' heel? International Journal of Sport Psychology, 24, 237-254. 
Brewer, B. (1994). Review and critique of models of psychological adjustment to athletic injury. Journal of Applied Sport Psychology, 6, 87-100.

Brewer, B., \& Petrie, T. (1996). Psychopathology in sport \& exercise. In J. L. Van Raalte \& B. Brewer (Eds.), Exploring Sport and Exercise Psychology (pp. 257-274), Washington, DC: American Psychological Association.

Brewer, B.W., Van Raalte, J. L., Peptitpas, A. J., Bachman, A. D., \& Weinhold, R. A. (1998). Newspaper portrayals of sport psychology in the United States, 1985-193. The Sport Psychologist, 12, 89-94.

Brewer, B., Van Raalte, J., \& Petitpas, A. (2000). Self-identity issues in sport career transitions. In D. Lavalee \& P. Wylleman (Eds.), Career Transition in Sport: International Perspectives. Morgantown, W. V.: Fitness Information Technology.

Broughton, E., \& Neyer, M. (2001). Advising and counseling student athletes. New Directions for Student Services, 93, 47-53.

Brown, G. T. (1999). The 'sanity code' leads the association down path to enforcement. The NCAA News. Retrieved on March 2, 2010 from www.ncaa.org .

Carr, K., Conway, K., Mundt, M., Brown, D., \& Thein-Nissenbaum, J. (2007). Division 1 Female College Athlete Health. Department of Family Medical Research, University of Wisconsin.

Chandler, T J. L., \& Goldberg, A. D. (1990). The academic All-American as a valued adolescent role-identity. Sociology of Sport Journal, 7, 27-293.

Coakley, J. (1983). Leaving competitive sport: Retirement or rebirth? Quest 35 (1),111.

Coakley, J. (1992). Burnout among adolescent athletes. Sociology of Sport 
Journal, 9, 271-285.

Coakley, J. (2007). Sports in Society: Issues and Controversies ( $9^{\text {th }}$ Edition). New York, NY: McGraw-Hill.

Coakley, J. (2009). Sports in Society: Issues and Controversies (10 ${ }^{\text {th }}$ Edition). New York, NY: McGraw-Hill Company.

Coakley, J., \& White, A. (1999). Making decisions: How young people become involved and stay in sports. In Jay Coakley and Peter Donnelly, (Eds.), Inside Sports, London: Routledge.

Donnelly, P., \& Young, K. (1988). The construction and confirmation of identity in sport subcultures. Sociology of Sport Journal, 5(3), 223-240.

Etzel, E. F. Ferrante, A.P., \& Pinkney, J.W. (1991) Counseling College Student Athletes: Issue and Interventions. Morgantown, WV: Fitness Information Technology.

Etzel, E. F., \& Pinkney, J. W. (2002). Counseling College Student Athletes: Issues and Interventions. Morgantown, WV: Fitness Information Technology.

Ferrante, A. P., Etzel, E., \& Lantz, C. (1996). Counseling college student athletes: The problem, the need. In E. Etzel, A. P. Ferrante, \& J. W. Pinkney (Eds.), Counseling College Student Athletes: Issues and Interventions. Morgantown, WV: Fitness Information Technology.

Ferraro, T., \& Rush, S. (2000). Why Athletes Resist Sport Psychology. Retrieved on January 27, 2010 from www.athleticinsight.com .

Figler, S., \& Figler, H. (1991). Going the Distance, Princeton, NJ: Figler \& Figler. Foley, D. E. (1990). The great American football ritual: reproducing race, class, and 
gender equality. Sociology of Sport Journal, 7(2), 111-135.

Frayne, C. A., \& Geringer, J.M. (2000). Self-Management Training For Improving Job Performance. Journal of Applied Psychology, 85(3), 361-372.

Frayne, C. A., \& Latham, G P. (1987). The application of social learning theory to employee self-management of attendance. Journal of Applied Psychology, 72, 387392.

Gallagher, R. P. (2005). National survey of counseling center directors. Alexandria, VA: International Association of Counseling Services.

Gelb, J. \& Palley, M. L. (1996). Title IX: The politics of sex discrimination. Women and Public Policies: Reassessing gender politics .Charlottesville: University of Virginia Press.

Gerber, E. W., Felshin, J., Berlin, P., \& Wyrick, W. (1974). The American Women in Sport. Reading, MA: Addison-Wesley.

Gerdy, J. R. (2002). The Successful College Athletic Program. Westport, CT: Oryx Press.

Gould, D., Lauer, L., Collins, K., \& Chung, Y. (2002). Examining Strategies Outstanding High School Football Coaches Use to Develop Life Skills and Character in Their Players. Executive Summary, NFL Charities Grant Project.

Griffin, J., Berry, E. M. (2003). A modern day holy anorexia? Religious language in advertising and anorexia nervosa in the west. European Journal of Clinical Nutrition, 5(1), 43-51.

Grove, J. R., Lavalee, D., \& Gordon, S. (1997). Coping from retirement from sports: The influence of athletic identity. Journal of Applied Sport Psychology, 9, 191-203. 
Hannon, J., Soohoo, S, Reel, T., \& Ratliffe, T. (2010). Gender stereotyping and the influence of race in sport among adolescents. Research Quarterly Exercise and Sport, 80(3), 676-679.

Hawes, K. (1999). The History of Interscholastic Athletics and the NCAA. Retrieved on January 25, 2010 from www.ncaa.org.

Higher Education Center for Alcohol, Drug Abuse, and Violence Prevention. (2003).

Retrieved on January 22, 2010 from HigherEdCtr@edc.org.

Hinkle, J. S. (1994). Practitioners and cross-cultural assessment: A practical guide to information and training. Measurement and Evaluation in Counseling and Development, 27, 103-115.

Horowitz, H.L. (1987). Campus Life: Undergraduate Cultures from the End of the Eighteenth Century to the Present. Chicago: University of Chicago Press.

Hudd, S.,Dumlao, J., Erdmann-Sager, D., Murray, D., Phan, E., Soukas, N., \& Yokozuka, N. (2000). Stress at college: Effects on health habits, health status, and self-esteem. College Student Journal, 34, 217-227.

Hult, J. S. (1994). The story of women's athletics: Manipulating a dream 1890-1985. In D. A. Costa \& S. R. Guthrie (Eds.), Women and Sport: Interdisciplinary Perspectives. (pp 83-107), Champaign, IL: Human Kinetics.

Humphrey, J. H., Yow, D. A., \& Bowden, W. W. (2000). Stress in College Athletics: Causes, Consequences, Coping. Binghamton, NY: The Haworth Half-Court Press. Inaba, D. S., \& Cohen, W. E. (1994). Uppers, Downers, All Arounders ( $2^{\text {nd }}$ Edition). Ashland, OR: CNS Productions.

Johnson, C., Crosby, R. D., Engel, S. G., Mitchell, J. E., Powers, P. S., Wittrock, D. A., 
\& Wonderlich, S. A. (2004). Gender, ethnicity, self-esteem and disordered eating among college athletes. Eating Behaviors, 5(2), 147-156.

Johnson, C., Powers, P. S., \& Dick, R. (1999). Athletes and eating disorders: The national collegiate athletic association study. International Journal of Eating Disorders, 26, 179-188.

Karoly, P. (1993). Mechanisms of self-regulation: A systems review. Annual Review of Psychology, 44, 23.

Kendall, D. (2008). Sociology in our Times ( $7^{\text {th }}$ Edition). Belmont, CA: Cengage Learning.

Kennedy, S., \& Domick, K. (1987). Career maturity and professional sports expectations of college football and basketball players. Journal of College Student Personnel, 28, 293-297.

Killeya-Jones, L. A. (2005). Identity structure, role discrepancies and psychological adjustment in male college athletes. Journal of Sport Behavior, 28, 167-185.

Kimball, A., \& Freysinger, V. J. (2003). Leisure, stress, and coping: the sport participation of collegiate student-athletes. Leisure Sciences, 25, 115-141.

Lever, J. (1983). Soccer Madness. Chicago: University of Chicago Press.

Levy. M. A., \& Gordon, L. (2005) Career transitions for athletes. In J. Taylor \& G. Wilson Applying Sport Psychology: Four Perspectives. (pp 260), Champaign, IL., Human Kinetics.

Locke, E. A., Frederick, E., Lee, C., \& Bobko, P. (1984). Effect of self-efficacy, goals, and task strategies on task performance. Journal of Applied Psychology, 69, 241251. 
Manz, C. C. (1986). Self-leadership: Toward an expanded theory of self-influence processes in organizations. Academy of Management Review, 11, 585-600.

Marcia, J. E. (1966). Development and validation of ego identity. In Pascarella, E. T., \& Terenzini, P. T. (1991). How College Affects Students. San Francisco, CA: JosseyBass Publishers.

Martens, M.P., Dams-O'Connor, K., \& Beck, N.C. (2006). A systematic review of college student athlete drinking: prevalence rates, sports-related factors, and interventions. Journal of Substance Abuse, 31(3), 305-316.

Marx, J., Huffman, S., \& Doyle, A. (2008). The student-athlete model and the socialization of intercollegiate athletes. Athletic Insight: The Online Journal of Sport Psychology, 10(1). Retrieved from www.athleticinsight.com on August 7, 2008.

Miller, B. E., Miller, M. N., Verhegge, R., Linville, H. H., \& Pumariega, A. J. (2002). Alcohol misuse among college athletes: self-medication for psychiatric symptoms. Journal of Drug Education, 32(1), 41-52.

Murray, M. A. (1997). The counseling needs of college student athletes. Dissertation Abstracts International, 58(6), 2088A.

NCAA (2005). Managing student athlete's mental health issues. Available online at www.ncaa.org/health-safety .

O'Connor, P. (1996). Eating disorder symptoms in former female college gymnasts: Relations with body composition. American Journal of Clinical Nutrition, 64, 840-43.

Ogilvie, B. C., \& Taylor, J. (1993). Career termination in sports: When the dream dies. In J. Williams (Ed.), Applied Sport Psychology: Personal Growth To Peak Performance. (pp. 356 - 365), Palo Alto, CA: Mayfield. 
Papanikolaou, Z., Nikolaidis, D.,Patsiaouras, A., \& Alexopoulos, P. (2003). The freshman experience: high stress-low grades. Athletic Insight: The Online Journal of Sports Psychology. Retrieved on September 4, 2008 from www.athleticinsight.com .

Park, R. J. \& Hult, J. S. (1993). Women as leaders in physical educational schoolbased sports, 1865 to the 1930's. The Journal of Physical Education, Recreation \& Dance, 64(3), 35-40.

Pascarella, E. T., \& Terenzini, P. T. (1991). How College Affects Students. San Francisco, CA: Jossey-Bass Publishers.

Pinkerton, R. S., Hinz, L.D. \& Barrow, J.C. (1989). The college studentathlete: psychological considerations and interventions. Journal of College Health, $37,218-226$.

Raedeke, T.D. (1997). Is athletic burnout more than just stress? Journal of Sport and Exercise Physiology, 19(4), 396-417.

Rigauer, B. (1981). Sport and Work. US: Columbia University Press, 1981.

Savage, H.J. (1929). American College Athletics. New York, NY: Carnegie Foundation. In J. R. Gerdy The Successful College Athletic Program. Westport, CT., Oryx Press.

Schmidt, G. W., \& Stein, G. L. (1991). Sport commitment: a model integrating enjoyment, dropout, and burnout. Journal of Sport and Exercise Psychology, 13, 254-265.

Selby, R., Weinstein, H. M., \& Bird, T.S. (1990) The health of university athletes: Attitudes, behaviors, and stressors. Journal of American College Health, 39:11-18. Shields, D. \& Bredemeier, B. (1995). Character development in physical activity. 
Champaign, IL: Human Kinetics.

Shirka, N. (1997). The relationship of hardiness, sense of coherence, sports participation and gender to perceived stress and psychological symptoms among college students. Dissertation Abstracts International Section A: Humanities and Social Sciences, 58, 0120.

Shurts, W. M., \& Shoffner, M. F. (2004). Providing career counseling for collegiate student-athletes: A learning theory. Journal of Career Development, 31(2), 95-109.

Silva, J. M. (1990). An analysis of the training stress syndrome in competitive athletics. Journal of Sport Psychology, 2, 5-20.

Sinclair, D. A., \& Hackfort, S. (2000). The role of the sport organization in the career transition process. In D. Lavallee \& P. Wylleman (Eds.), Transitions in Competitive Sports. Morgantown, W. V.: Fitness Information Technology.

Smith, R. E. (1986). Toward a cognitive-affective models of athletic burnout. The Journal of Sport Psychology, 8, 36-50.

Smolak, L. et al. (2000) Female athletes and eating problems: A meta-analysis. International Journal of Eating Disorders, 27, 371-80.

Stevenson, C. (1999). Becoming an elite international athlete: making decisions about identity. In Jay Coakley and Peter Donnelly (Eds.), Inside Sports, London: Routledge.

Street, J. M. (1999). Self efficacy: a tool for providing effective support services for student-athletes. In S. Robinson (Ed.), Gaining the Competitive Edge: Enriching the Collegiate Experience of the New Student Athlete. Columbia: National Resource Center for First Year Experience of Students in Transition, University of South 
Carolina, 1999.

Tajifel, H. \& Turner, J. C. (1986). The social identity theory of intergroup behavior. In S. Worchell \& W. Austin (Eds.), Psychology of intergroup relations (pp. 7-24). Chicago: Nelson Hall.

Taylor, J., \& Ogilvie, B. C. (1994). A conceptual model of adaptation to retirement among athletes. Journal of Applied Sport Psychology, 6, 1-20.

Taylor, J. \& Wilson, G. (2005). Applying Sport Psychology. Champaign, IL., Human Kinetics.

Thombs, D. L. (2000). A test of the perceived norms model to explain drinking patterns among university student athletes. Journal of American College Health, 49, 75-83.

Torstveit, M., \& Sundgot-Borgen, J. (2005). The female athlete triad exists in both elite athletes and controls. Medicine and Science in Sports and Exercise, 37, 1449-59.

Watson, J. C. (2002). Assessing the Potential for Alcohol-Related Issues Among College Student-Athletes. Retrieved on January 27, 2010 from www.athleticinsight.com .

Watson, J. C. (2003) Overcoming the challenges of counseling college student athletes. Retrieved on September 4, 2008, from www.ericdigest.org .

Watson, J. C. (2005). College student athlete's attitudes toward a help-seeking behavior and expectations of counseling services. Journal of College Student Development, $46(4), 442-449$.

Watson, J. C., \& Kissinger, D. B. (2007). Athletic participation and wellness: Implications for counseling college student-athletes. Journal of College Counseling. 10(2), 153163. 
Watt, S. K. \& Moore, J. L. (2001). "Who are student athletes?" New Directions for Student Services, 93, 7-18.

Webb, W. M., Nasco, S. A., Riley, S., \& Headrick, B. (1998). Athlete identity and reactions to retirement from sport. Journal of Sports Behavior, 21, 338-362.

Weinberg, R. S., \& Gould, D. (1999). Foundations of sport and exercise psychology. (3 ${ }^{\text {rd }}$ Edition). Champaign, IL: Human Kinetics.

Williams, M. H. (2007). Nutrition for Health, Fitness, \& Sport ( $8^{\text {th }}$ Edition). New York, N.Y: McGraw-Hill Company.

Wilson, G., \& Pritchard, M. (2005). Comparing sources of stress in college student athletes and non-athletes. Retrieved on September 4, 2008, from www.athleticinsight.com .

Wood, R., \& Bandura, A. (1989). Social cognitive theory of organizational management. Academy of Management Review, 14,361-384.

Zimbalist, A. (1999). Unpaid Professional: Commercialism and Conflict in Big-Time College Sports. Princeton, NJ: Princeton University Press. 
Appendix A

Reflections of Former California Polytechnic State University Student Athletes (1970's through 2009)

Transition to college life can be difficult for any student; however, researchers suggest that athletes experience significantly more difficulties due to the expectation that they perform both academically and athletically. In addition to the many academic demands faced by all college students, athletes must cope with athletic related issues such as stress of performance, time management due to practice and competitive events, physical injury, and sports-related career transitions. Correspondence with Cal Poly alumni was conducted to examine the social and psychological challenges faced by former Cal Poly student athletes. These recollections will contribute to the creation of a mandatory course intended to assist current and future Cal Poly student athletes as they transition into university life.

When you experienced stress and/or anxiety, where did you seek help?

- "I never considered seeking help for my stress and anxiety. During my two years playing basketball, (following two years of basketball @ the Community College level), my performance level was significantly below my and the coaching staffs' expectations. My stamina and energy levels were basically non-existent throughout my career. I would typically become out of breath after the first couple of trips up and down the court. I was never able to figure out the cause of this issue. It was likely due to inadequate and/or misdirected physical training compounded by the stress of continuing poor performance".

- When I felt stressed or anxious, I got support from my family and girlfriend.

- It is a strong part of human nature to never admit weakness or fear.

- In high school, I was able to confide in one of my coaches. In college, I pretty much kept my problems to myself.

- I usually hung out with a couple of team members and confided in them.

- When I felt stressed, I usually mellowed out by hanging out with friends and engaging in a little extra partying. In retrospect, I realize that wasn't the best choice but it's what most of us did at the time.

- I talked to a campus counselor once. We ended up talking mostly about my academic issues but never really got around to talking about the personal issues that were impacting my life.

What athletic, academic, and personal challenges did you face as a student athlete?

- "The stress and pressure of poor performance on the basketball court and the anxiety that accompanies failure to achieve expected performance. This failure 
impacted my academic and personal life. I was able to re-gain some self-esteem when I was given the opportunity to play football @ Cal Poly in my fifth year of eligibility. We had a very good team that had success and came close to having a really outstanding season. I developed many new personal relationships and experienced a satisfactory level of personal achievement especially in terms of what my expectations and the coaching staffs' expectations were for me".

- "Small High School to Poly adjustment, Knee injury w/ surgery after $1^{\text {st }}$ season, time management issues with classes, practice, games, social activity".

- "As a student athlete, the challenge was finding balance between the two roles; 1) student, (2) athlete. This was especially true during the season. As an athlete, there is more to do than just practice. Our team had workouts prior to practice and film analysis of our opponents to complete after practice. In addition, I was a biology student so I had to balance lab work and homework as well. Time management of my studies was how I overcame the challenges".

- There is more to do than just practice. We often traveled great distances for our games. During the season, we were sometimes on the road from Thursday to Sunday. It seems like I was always tired.

- Our team had workouts prior to practice and film analysis of our opponents to complete after practice. There wasn't much time for anything else but sleep.

- I suffered emotionally from a death in my family. During that time it was very difficult to do what I needed to do as an athlete and as a student but I didn't feel like there was anyone I could talk to about my problems.

- I suffered a career ending injury in my senior year. I blew out my knee and felt as though all my hopes and dreams were wiped out.

What were your academic and athletic expectations when you first arrived on the Cal Poly campus? Did those expectations change from your freshman (or transfer) year to your senior year?

- "My academic expectations were quite modest. I choose Physical Education as a major by default. My Mother was a teacher so I assumed that coaching and teaching could be a career for me after college. I saw myself strictly as an athlete. The academic opportunity provided to me @ Cal Poly was not a priority. My athletic expectations were to be a two year basketball starter, improve my game and productivity consistently and be in the position to play basketball professionally in Europe".

- "Athletically, the expectations grew significantly from freshman to senior as I went from a part-time player to a starter. Academically, the expectations also 
grew as I advanced from primarily general education courses into courses to complete my major. The intensity of those expectations, however, was far more significant in pursuit of my athletic goals as we sought and achieved a national championship".

- "I was surprised to find that I really enjoyed and was challenged by the Physical Education curriculum. I was relatively successful in all of my classes and actually excelled in kinesiology, human anatomy and statistics. My expectations did change, positively in terms of increased academic emphasis and success, from my transfer year to my senior year. I did not end up in the coaching/teaching field but I feel that my academic experience @ Cal Poly was very solid."

Describe any conflicts you felt between your academic and athletic roles. Did you give more time to one role over another? Did those expectations change from your freshman (or transfer) year to your senior year?

- "Initially athletic role was top priority with majority of time committed to performing well athletically. Academic role became higher priority as senior year approached".

- "My approach to balancing the two was to take a lighter academic class schedule or less challenging schedule during the season (fall) and then load up during the winter with a more difficult class schedule. This seemed to keep my on track throughout college".

- I came to college to play sports.

- I saw myself strictly as an athlete.

- My goal was to become a professional athlete so I focused on athletics.

- My sport came first. Then if I had extra time, I studied and did homework.

- I got almost all of my esteem from being a successful athlete. I wanted to do well as a student but I just wasn't as vested in my academic goals, as I was my athletic goals.

- School was just something else to deal with after my athletic and social obligations.

Do you feel that you had the necessary skills to successfully transition out of sport and into a career?

- "Absolutely not. Once I was no longer an athlete, I completely lost the personal identity that had been so important to me since middle school. It was not until nearly fifteen years later, when I was able to start my own that family, that I regained a new sense of identity and purpose that needed to be replaced when 
my athletic career ended. My basketball career@ Cal Poly continued to be a significant reminder that I had failed before and would likely fail again."

- "I do think that both my academic experience and my athletic experience gave me the skills to succeed. In my opinion, college teaches you to meet deadlines and complete projects in a timely manner. Time management is a key skill in succeeding in a career. College also gives you a sense of achievement through the attainment of a degree. Athletics adds to that experience by also teaching you goal setting, discipline and teamwork. These characteristic also transcends athletics into a successful career."

How can the university, community, faculty, and athletic staff encourage student athletes to acknowledge and equally value their role as students and athletes?

- "Generate methods for productively challenging students and athletes to be open and willing to discuss issues that are causing them stress, insecurity and on-going personal disappointment. These methods are more available to students today. Open discussions in small peer groups is a great environment to stimulate openness. The crucial ingredient however is the presence of instructor/leaders who are capable of directing the openness into learning and realization opportunities.

- This issue of developing and supporting the process by which athletes can develop a non-athletic identity should be a big priority, from my perspective. This is a very difficult task.

- It is crucial to try, early on, to stress to athletes that it is the academic and future career opportunities that will most help to set them up for success in life. It is a hard sell but it should be repeated often that academic achievement should be given equal if not greater emphasis than athletic achievement."

- Stress the importance of the education available at Cal Poly and what that education can do for a successful student athlete throughout their life.

- "Creating balance can be forced through consistent and regulated grade checks. We were required to turn in mid-quarter grade checks throughout the school year.

- Communication with student athletes is also important. Too often coaches focus on the performance of the athlete and don't take the time to ask how the student is doing in school... and more importantly, how can they help.

- Academic faculty should also have greater appreciation for the difficulty student-athletes face in balancing their roles. Some professors are very good at providing open access through extended office hours. Others, quite frankly, 
go the opposite direction and seem to make it more difficult on student athletes as their own views do not support any type of duality in the student's role.

- Study session and homework assistance is also important. We did not have homework assistance, so I had to make sure that I went to the library or student union before I returned to my room."

- I got many awards and commendations for my athletic ability but very few for my academic achievements...and I was a good student.

- My time@ Cal Poly is still so vivid to me even though I lived that life a long time ago. 
Appendix B

Course Syllabus

Transition Into, Through, and Beyond College Life

$\begin{array}{ll}\text { Meeting Days/Time: } & \text { TBA } \\ \text { Instructor: } & \text { TBA } \\ \text { Office: } & \text { TBA } \\ \text { Mailbox: } & \text { TBA } \\ \text { Office Phone: } & \text { TBA } \\ \text { E-mail: } & \text { TBA } \\ \text { Office Hours: } & \text { TBA }\end{array}$

Course Description: A theory-based self-management training program to provide student athletes with behavioral and cognitive strategies that promote a healthy adaptation to the specific demands of their dual role. The course is structured to include lectures, small group presentations, and one-on-one meetings.

Course Purpose: The purpose of this course is to provide the opportunity for student athletes to acquire the knowledge and skills necessary to improve their personal effectiveness as both students and athletes as they transition into, through, and beyond college life. Course topics relate to current issues and challenges relevant to intercollegiate athletics and supported by research.

Expected Outcomes: By the end of the quarter, students will

- Create a student athlete self management tool kit which contains a set of behaviors and cognitive strategies that assist individuals in structuring their environment, establishing self-motivation, and facilitating behavior appropriate for successful behavior

- Create a broad-based set of skills and knowledge combined with unique social experiences that will facilitate growth in each student athlete's global self-concept

- Design a contingency plan to be implemented when faced with personal, social, and psychological diversity

- Specify a plan for successful transition out of sport and create a personal career plan

Course Objectives: By the end of the quarter, students will

- Assess and identify personal, athletic, and academic target behaviors

- Establish short and long term goals based on the behaviors identified in the self assessment

- Develop a system to monitor and evaluate progress toward goals

- Examine student athlete academic and athletic role identities to determine how they may change over the course of the college experience 
- Compose an autobiography

- Compare and contrast the attributes of successful students and athletes

- Establish heterogeneous learning teams led by selected mentors to discuss methods to broaden one's identity

- $\quad$ List potential academic, athletic, and personal challenges that student athletes experience

- Assess available campus and community support services

- Investigate student athlete resistance toward the utilization of support services

- Identify the challenges related to transition out of sport

- Identify the characteristics and skills of college athletes that are transferable to the working world

Course Assessments: By the end of the quarter, students will

- Create a self-management portfolio that includes the target behaviors, goals, monitoring and evaluation systems, behavioral contract, and a reflective essay

- Create a collective portfolio of personal reflections on case studies specific to student athlete issues and challenges

- Create a resume and write a reflection paper focused on the personal and athletic skills that contribute to successful career transition

- Group presentation on how to be successful in academics, athletics, and life

\section{Course Evaluation:}

Self-management portfolio

Case studies collective portfolio

Resume

Reflection paper

Group presentation

Course activities (4)

TOTAL

\section{Grading Scale:}

A $\quad 95-100 \%$

A- $\quad 90-94 \%$

B+ $\quad 85-89 \%$

B $\quad 80-84 \%$

B- $\quad 75-79 \%$

C+ $70-74 \%$

C $\quad 65-69 \%$

C- $\quad 60-64 \%$

D+ $55-59 \%$

D $\quad 50-54 \%$

F $\quad$ Below $50 \%$
80 points

25 points

25 points

25 points

25 points

20 points

200 points 


\section{Course Calendar}

(Subject to change with notice)

\begin{tabular}{|c|c|c|}
\hline Date & Topic(s) & Assignments \\
\hline & $\begin{array}{l}\text { Course overview and } \\
\text { expectations; Culture } \\
\text { shock }\end{array}$ & \\
\hline & $\begin{array}{l}\text { Negotiating the } \\
\text { academic setting; } \\
\text { Campus and community } \\
\text { resources }\end{array}$ & Campus resources team project \\
\hline & $\begin{array}{l}\text { Self-management: } \\
\text { Learning to manage } \\
\text { your own behavior }\end{array}$ & Self management data collection \\
\hline & $\begin{array}{l}\text { Self-selected goal } \\
\text { setting } \\
\text { Campus resource } \\
\text { presentations }\end{array}$ & Establish short term goals \\
\hline & Goal setting continued & Establish long term goals \\
\hline & $\begin{array}{l}\text { Monitoring and } \\
\text { evaluation systems }\end{array}$ & Establish self-monitoring process \\
\hline & Self evaluation & $\begin{array}{l}\text { Develop self-reinforcement and self-punishment } \\
\text { strategies }\end{array}$ \\
\hline & $\begin{array}{l}\text { Individual written } \\
\text { behavioral contracts }\end{array}$ & Prepare written agreement \\
\hline & $\begin{array}{l}\text { Maintenance and } \\
\text { relapse prevention }\end{array}$ & Identify high-risk situations \\
\hline & $\begin{array}{l}\text { Sports and socialization; } \\
\text { Sports and education; }\end{array}$ & Athletic event \\
\hline & $\begin{array}{l}\text { Dual role, role identity } \\
\text { and global self concept }\end{array}$ & Community service project \\
\hline & $\begin{array}{l}\text { Student athlete } \\
\text { challenges and issues }\end{array}$ & $\begin{array}{l}\text { Revisit self-management plan } \\
\text { Selected Reading }\end{array}$ \\
\hline & Time management & Selected Reading \\
\hline & $\begin{array}{l}\text { Mood and anxiety } \\
\text { disorders }\end{array}$ & Selected Reading \\
\hline & $\begin{array}{l}\text { Body image and } \\
\text { disordered eating }\end{array}$ & Selected Reading \\
\hline & $\begin{array}{l}\text { Performance nutrition } \\
\text { and performance } \\
\text { enhancing agents }\end{array}$ & Selected Reading \\
\hline & $\begin{array}{l}\text { Diversity in the } \\
\text { community }\end{array}$ & Campus Cultural Event \\
\hline
\end{tabular}




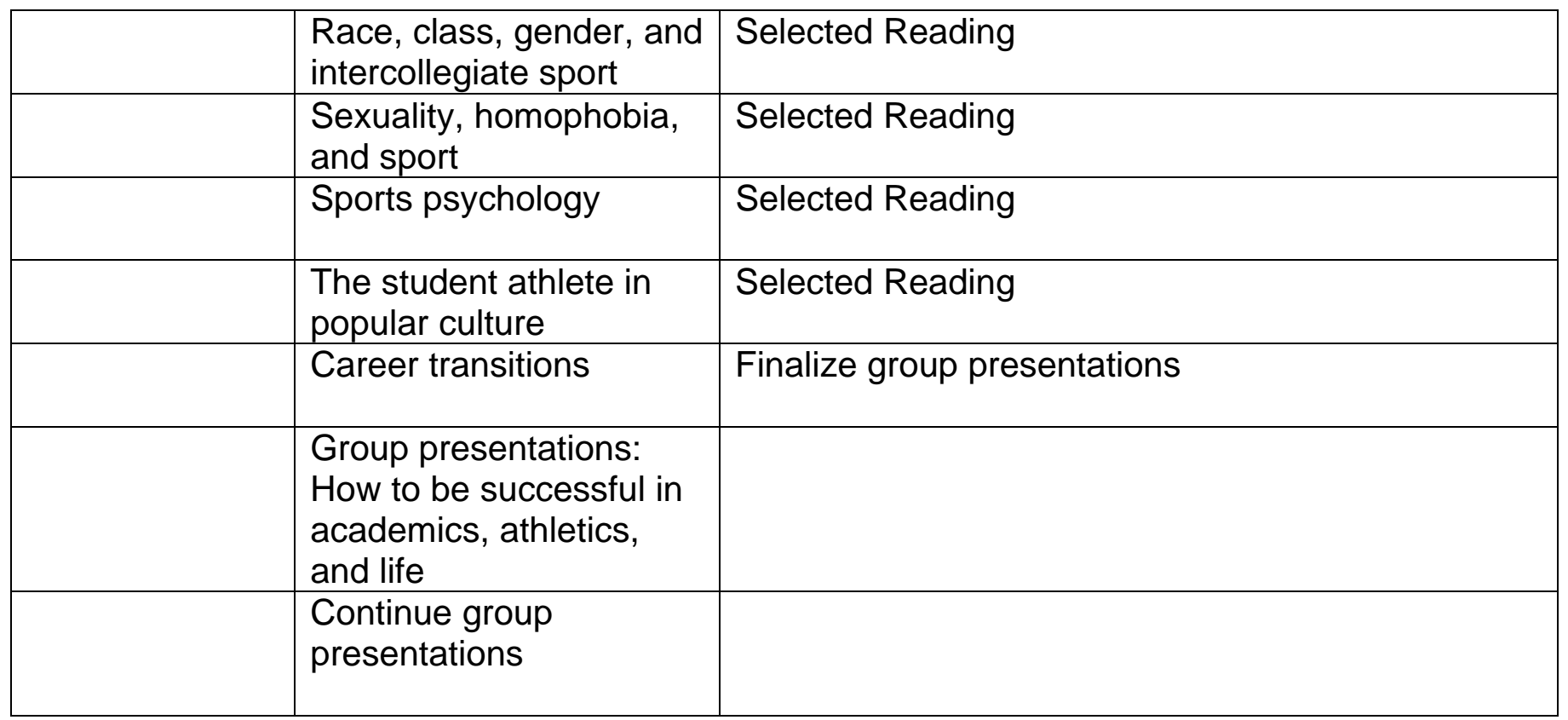

Reasonable course modifications and/or accommodations will be provided to students who have disabilities that may affect their ability to participate in course activities or to meet course requirements. Please contact the instructor as soon as possible to discuss individual needs.

\section{Course requirements}

- Self-management Portfolio (80 points)

o Self- Management Data Collection: Gather data about the target behaviors you wish to improve or modify. This activity will be a means of interpreting and changing individual behavior.

o Goal Setting: On the basis of the behaviors identified during selfassessment, establish several goals (short and long-term). This will provide direction for your individual efforts, avoiding what might otherwise be sporadic, reactionary activity lacking a consistent, purposeful basis.

o Self Monitoring Process: Maintain a record of your progress toward goal attainment. This process will provide you with data regarding progress 
toward attainment of your set goals. These data subsequently will become the basis for self evaluation.

o Self Evaluation: Develop self-reinforcement and self-punishment strategies on the basis of your performance relative to your set goals. By providing rewards for achieving your goals, a positive influence on future actions can be exerted. Use of self-administered punishers attempts to reduce the incidence of undesired behaviors.

o Written Contracts: Write an agreement for yourself that specifies expectations, plans, and contingents for behavior to be changed. The contract is a precursor to administration of the self management program; it will prompt you to follow through on the planned course of action and serves as an additional goal commitment.

o Maintenance and relapse prevention: Identify common problems and pitfalls in effectively applying self-management techniques and develop procedures for overcoming these circumstances. Identify high-risk situations that may cause you to stop engaging in self-managing behavior to prevent relapses by helping you to learn to recognize and avoid or overcome these potential drawbacks.

o Reflective Essay: Write an essay that summarizes the behavioral and cognitive strategies that you developed to structure your environment, establish self-motivation, and facilitate behaviors appropriate to promote a healthy adaptation to the specific demands of your dual role.

- Case Studies Collective Portfolio (25 points)

o Create a collective portfolio of personal reflections on case studies specific to student athlete issues and challenges

- Resume (25 points)

o Create a general resume

- Reflection Paper(25 points)

o Write a reflection paper focused on the personal and athletic skills that you have acquired through sport that will contribute to a successful career transition.

- Group Presentation (25 points)

o Prepare a group presentation on how to be successful in academics, athletics, and life

\section{Additional Course Activities}

- Campus Resources Team Project (5 points)

- With your team, visit a campus support service. As a group, prepare a 510 minute oral presentation about the resource. Provide a general overview and details of key services.

- Campus Cultural Event (5 points)

o Attend one campus event and write an account of the experience. Include the following information: date of the experience, reason for selecting the event, a 1 page summary of the event, and your reaction to the experience. Attach an event program, ticket stub, or other attendance 
confirmation, if applicable. Options include a play, a concert, a multicultural event, a lecture, or other similar event.

- $\quad$ Athletic Event (5 points)

o Attend one Cal Poly athletic event that is not your own. Write a brief 2 paragraph description of the event and the outcome. Attach a program or ticket stub, if applicable.

- Community Service Project (5 points)

o Complete 6 community service hours at an institution or event of your choice. Options include institutions such as hospitals, schools, churches, women's shelters, homeless shelter, retirement homes, or events such as Special Olympics and Read Across America. Write a 1 page summary of your experience. 


\section{Appendix C}

\section{Course Rubrics}

Group Presentation Rubric

Criteria

Levels of Achievement

\begin{tabular}{|c|c|c|c|c|}
\hline & 4 Excellent & 3 Good & 2 Fair & 1 Poor \\
\hline $\begin{array}{l}\text { Overall } \\
\text { Organization }\end{array}$ & $\begin{array}{l}\text { Very well- } \\
\text { structured, clear, } \\
\text { logical and easy } \\
\text { to follow }\end{array}$ & $\begin{array}{l}\text { Mostly well- } \\
\text { structured and } \\
\text { clear with a few } \\
\text { minor points } \\
\text { unconnected or } \\
\text { confusing }\end{array}$ & $\begin{array}{l}\text { Somewhat } \\
\text { structured but } \\
\text { several } \\
\text { disjointed parts }\end{array}$ & $\begin{array}{l}\text { Unstructured, out } \\
\text { of logical order, } \\
\text { strays from } \\
\text { subject }\end{array}$ \\
\hline $\begin{array}{l}\text { Audience } \\
\text { Awareness }\end{array}$ & $\begin{array}{l}\text { Appropriate } \\
\text { level, pacing and } \\
\text { volume; } \\
\text { significantly } \\
\text { increases } \\
\text { understanding } \\
\text { and knowledge } \\
\end{array}$ & $\begin{array}{l}\text { Generally } \\
\text { appropriate level, } \\
\text { pacing and } \\
\text { volume; raises } \\
\text { understanding } \\
\text { and knowledge } \\
\text { on most points } \\
\end{array}$ & $\begin{array}{l}\text { Inconsistent } \\
\text { level, pacing and } \\
\text { volume; raises } \\
\text { understanding } \\
\text { and knowledge } \\
\text { of some points }\end{array}$ & $\begin{array}{l}\text { Inappropriate } \\
\text { level, pacing and } \\
\text { volume; fails to } \\
\text { increase } \\
\text { understanding } \\
\text { and knowledge }\end{array}$ \\
\hline Delivery & $\begin{array}{l}\text { Relaxed, self- } \\
\text { confident, } \\
\text { appropriately } \\
\text { dressed' direct } \\
\text { eye contact with } \\
\text { entire audience, } \\
\text { good volume and } \\
\text { inflection }\end{array}$ & $\begin{array}{l}\text { Generally } \\
\text { relaxed and } \\
\text { appropriately } \\
\text { dressed, } \\
\text { somewhat } \\
\text { consistent eye } \\
\text { contact, } \\
\text { satisfactory } \\
\text { volume and } \\
\text { inflection }\end{array}$ & $\begin{array}{l}\text { Somewhat tense } \\
\text { and } \\
\text { uncomfortable, } \\
\text { minimal eye } \\
\text { contact, } \\
\text { questionable } \\
\text { dress, } \\
\text { inconsistent } \\
\text { volume, little or } \\
\text { no inflection }\end{array}$ & $\begin{array}{l}\text { Nervous, tense, } \\
\text { inappropriately } \\
\text { dressed, no } \\
\text { direct eye } \\
\text { contact, low } \\
\text { volume, } \\
\text { monotone }\end{array}$ \\
\hline Visual Aids & $\begin{array}{l}\text { High quality, } \\
\text { useful, good } \\
\text { variety, } \\
\text { enhances } \\
\text { presentation }\end{array}$ & $\begin{array}{l}\text { Mostly high } \\
\text { quality with some } \\
\text { variety, } \\
\text { contributes to } \\
\text { presentation }\end{array}$ & $\begin{array}{l}\text { Some quality but } \\
\text { little variety, } \\
\text { questionable } \\
\text { value }\end{array}$ & $\begin{array}{l}\text { No visual aids or } \\
\text { unimportant, } \\
\text { inadequate aids } \\
\text { of no value }\end{array}$ \\
\hline Teamwork & $\begin{array}{l}\text { All members } \\
\text { take an active } \\
\text { role, clear } \\
\text { definition of } \\
\text { tasks, good } \\
\text { transitions, topic } \\
\text { well-covered }\end{array}$ & $\begin{array}{l}\text { Most members } \\
\text { take an active } \\
\text { role, tasks are } \\
\text { understood, } \\
\text { adequate } \\
\text { transitions, topic } \\
\text { covered } \\
\text { adequately }\end{array}$ & $\begin{array}{l}\text { Inconsistent } \\
\text { participation, } \\
\text { some task } \\
\text { confusion, } \\
\text { transitions } \\
\text { disorganized, } \\
\text { audience left } \\
\text { with questions }\end{array}$ & $\begin{array}{l}\text { Inequitable } \\
\text { participation, little } \\
\text { cohesion, much } \\
\text { task confusion, } \\
\text { poor transitions, } \\
\text { topic not } \\
\text { adequately } \\
\text { covered }\end{array}$ \\
\hline
\end{tabular}


Reflective Writing Rubric

Criteria Levels of Achievement

\begin{tabular}{|l|l|l|l|l|}
\hline & 4 Excellent & 3 Good & 2 Fair & Poor \\
\hline $\begin{array}{l}\text { Extent of } \\
\text { Reflection }\end{array}$ & $\begin{array}{l}\text { Effectively } \\
\text { identifies issue } \\
\text { or situation, } \\
\text { conveys } \\
\text { insightful and } \\
\text { thorough } \\
\text { analysis }\end{array}$ & $\begin{array}{l}\text { Clearly identifies } \\
\text { issue or } \\
\text { situation, } \\
\text { conveys } \\
\text { thoughtful } \\
\text { analysis }\end{array}$ & $\begin{array}{l}\text { Identifies issue } \\
\text { or situation, } \\
\text { conveys basic } \\
\text { understanding } \\
\text { and some } \\
\text { analysis }\end{array}$ & $\begin{array}{l}\text { Identifies issue } \\
\text { or situation, } \\
\text { conveys little or } \\
\text { no } \\
\text { understanding or } \\
\text { analysis }\end{array}$ \\
\hline $\begin{array}{l}\text { Use of } \\
\text { evipporting }\end{array}$ & $\begin{array}{l}\text { Specific and } \\
\text { convincing } \\
\text { examples, } \\
\text { makes insightful } \\
\text { connections }\end{array}$ & $\begin{array}{l}\text { Relevant } \\
\text { examples, some } \\
\text { insightful } \\
\text { connections }\end{array}$ & $\begin{array}{l}\text { Limited, vague } \\
\text { examples with } \\
\text { minimal } \\
\text { connections }\end{array}$ & $\begin{array}{l}\text { Few or no } \\
\text { examples, } \\
\text { irrelevant, } \\
\text { unsupported, } \\
\text { and } \\
\text { disconnected }\end{array}$ \\
\hline Language & $\begin{array}{l}\text { Sophisticated, } \\
\text { precise, voice } \\
\text { and purpose } \\
\text { apparent, varied } \\
\text { sentence } \\
\text { structure }\end{array}$ & $\begin{array}{l}\text { Some } \\
\text { sophistication, } \\
\text { clear, voice and } \\
\text { purpose evident, } \\
\text { some variance in } \\
\text { sentence } \\
\text { structure }\end{array}$ & $\begin{array}{l}\text { Somewhat } \\
\text { vague and } \\
\text { imprecise, } \\
\text { limited voice, } \\
\text { purpose unclear, } \\
\text { limited variance } \\
\text { in sentence } \\
\text { structure }\end{array}$ & $\begin{array}{l}\text { Vague, } \\
\text { imprecise, } \\
\text { inappropriate for } \\
\text { audience and } \\
\text { purpose, no } \\
\text { awareness of } \\
\text { sentence } \\
\text { structure }\end{array}$ \\
\hline Conventions & $\begin{array}{l}\text { Consistent } \\
\text { control of } \\
\text { conventions with } \\
\text { no errors }\end{array}$ & $\begin{array}{l}\text { Consistent } \\
\text { control of } \\
\text { conventions with } \\
\text { a few errors }\end{array}$ & $\begin{array}{l}\text { Some control of } \\
\text { conventions with } \\
\text { errors that limit } \\
\text { comprehension }\end{array}$ & $\begin{array}{l}\text { Little or no } \\
\text { control of } \\
\text { conventions with } \\
\text { errors that inhibit } \\
\text { comprehension }\end{array}$ \\
\hline
\end{tabular}


Portfolio Rubric

Criteria

Levels of Measurement

\begin{tabular}{|l|l|l|l|l|}
\hline & 4 Excellent & 3 Good & 2 Fair & 1 Poor \\
\hline Artifacts & $\begin{array}{l}\text { All artifacts } \\
\text { clearly and } \\
\text { specifically } \\
\text { related to } \\
\text { purpose, well- } \\
\text { developed }\end{array}$ & $\begin{array}{l}\text { Most artifacts } \\
\text { related to } \\
\text { purpose, } \\
\text { adequately } \\
\text { developed }\end{array}$ & $\begin{array}{l}\text { Very few artifacts } \\
\text { related to } \\
\text { purpose, } \\
\text { somewhat } \\
\text { developed }\end{array}$ & $\begin{array}{l}\text { Most artifacts } \\
\text { unrelated to } \\
\text { purpose, poorly } \\
\text { developed or } \\
\text { incomplete }\end{array}$ \\
\hline Reflections & $\begin{array}{l}\text { All reflections } \\
\text { clearly describe } \\
\text { artifacts and how } \\
\text { they pertain to } \\
\text { the individual }\end{array}$ & $\begin{array}{l}\text { Most reflections } \\
\text { describe the } \\
\text { artifacts and how } \\
\text { they pertain to } \\
\text { the individual }\end{array}$ & $\begin{array}{l}\text { Some reflections } \\
\text { describe the } \\
\text { artifacts and how } \\
\text { they pertain to } \\
\text { the individual }\end{array}$ & $\begin{array}{l}\text { Few or no } \\
\text { reflections } \\
\text { describe the } \\
\text { artifacts and how } \\
\text { they pertain to } \\
\text { the individual }\end{array}$ \\
\hline $\begin{array}{l}\text { Visual Appeal } \\
\text { Creativity }\end{array}$ & $\begin{array}{l}\text { Clear, precise, } \\
\text { professional } \\
\text { format, easy to } \\
\text { read, original } \\
\text { ideas }\end{array}$ & $\begin{array}{l}\text { Clear, somewhat } \\
\text { orderly, evidence } \\
\text { of original ideas }\end{array}$ & $\begin{array}{l}\text { Lacks clarity, } \\
\text { difficult to read, } \\
\text { little use of } \\
\text { original ideas }\end{array}$ & $\begin{array}{l}\text { Unclear, } \\
\text { imprecise, no } \\
\text { evidence of } \\
\text { original ideas }\end{array}$ \\
\hline Organization & $\begin{array}{l}\text { Content clearly } \\
\text { arranged in a } \\
\text { precise and } \\
\text { logical manner }\end{array}$ & $\begin{array}{l}\text { Content } \\
\text { generally } \\
\text { arranged in a } \\
\text { precise and } \\
\text { logical manner }\end{array}$ & $\begin{array}{l}\text { Some content } \\
\text { arrange in a } \\
\text { careless manner }\end{array}$ & $\begin{array}{l}\text { Content poorly } \\
\text { and illogically } \\
\text { placed, some } \\
\text { elements missing }\end{array}$ \\
\hline
\end{tabular}


Resume Rubric

Criteria

Levels of Measurement

\begin{tabular}{|c|c|c|c|c|}
\hline & 4 Excellent & 3 Good & 2 Fair & 1 Poor \\
\hline Content & $\begin{array}{l}\text { Includes } \\
\text { heading, } \\
\text { objective, } \\
\text { education, } \\
\text { experience, } \\
\text { honors/activities, } \\
\text { extra details to } \\
\text { augment basic } \\
\text { information }\end{array}$ & $\begin{array}{l}\text { Includes } \\
\text { heading, } \\
\text { objective, } \\
\text { education, } \\
\text { experience, } \\
\text { honors/activities, } \\
\text { extra details to } \\
\text { augment basic } \\
\text { information }\end{array}$ & $\begin{array}{l}\text { Includes } \\
\text { heading, } \\
\text { objective, } \\
\text { education, } \\
\text { experience, } \\
\text { honors/activities, } \\
\text { few additional } \\
\text { details }\end{array}$ & $\begin{array}{l}\text { Omits some } \\
\text { basic } \\
\text { information, no } \\
\text { additional details }\end{array}$ \\
\hline Presentation & $\begin{array}{l}\text { Well-designed, } \\
\text { visually } \\
\text { appealing, typed } \\
\text { or computer } \\
\text { generated, } \\
\text { format highlights } \\
\text { information, } \\
\text { appropriate } \\
\text { margins and font }\end{array}$ & $\begin{array}{l}\text { Adequately } \\
\text { designed, } \\
\text { visually } \\
\text { adequate, typed } \\
\text { or computer } \\
\text { generated, } \\
\text { format } \\
\text { distinguishes } \\
\text { information, } \\
\text { appropriate } \\
\text { margins and font }\end{array}$ & $\begin{array}{l}\text { Lacks adequate } \\
\text { design, visually } \\
\text { acceptable, } \\
\text { typed or } \\
\text { computer } \\
\text { generated, } \\
\text { format identifies } \\
\text { information, } \\
\text { margins lack } \\
\text { balance, fonts } \\
\text { lack variation }\end{array}$ & $\begin{array}{l}\text { Poorly designed, } \\
\text { visually } \\
\text { unacceptable, } \\
\text { typed or } \\
\text { computer } \\
\text { generated, } \\
\text { format and font } \\
\text { detracts from } \\
\text { information, } \\
\text { unacceptable } \\
\text { margin }\end{array}$ \\
\hline Information & $\begin{array}{l}\text { Accurate, } \\
\text { complete, } \\
\text { polished, } \\
\text { specific, reveals } \\
\text { ability to perform } \\
\text { job, professional } \\
\text { terminology }\end{array}$ & $\begin{array}{l}\text { Accurate, } \\
\text { complete, } \\
\text { specific, reveals } \\
\text { ability to perform } \\
\text { job, some } \\
\text { professional } \\
\text { terminology }\end{array}$ & $\begin{array}{l}\text { Generally } \\
\text { accurate, } \\
\text { complete, } \\
\text { reveals ability to } \\
\text { perform job }\end{array}$ & $\begin{array}{l}\text { Errors, missing } \\
\text { information, } \\
\text { does not reveal } \\
\text { ability to perform } \\
\text { job }\end{array}$ \\
\hline Mechanics & $\begin{array}{l}\text { No spelling or } \\
\text { grammar errors }\end{array}$ & $\begin{array}{l}\text { Minimal spelling } \\
\text { and grammar } \\
\text { errors }\end{array}$ & $\begin{array}{l}\text { Several spelling } \\
\text { and grammar } \\
\text { errors }\end{array}$ & $\begin{array}{l}\text { Many spelling } \\
\text { and grammar } \\
\text { errors }\end{array}$ \\
\hline
\end{tabular}

